Федоренко О. Б.

ст. викладач

Національний транспортний університет

\title{
ДУХОВНА НАСНАГА КОЗАКІВ-ХАРАКТЕРНИКІВ (ЗА РОМАНОМ П. ПАНЧА «ГОМОНІЛА УКРАЇНА»)
}

У статті досліджено незвичайні прояви козаків у романі П. Панча «Гомоніла Україна». Увагу приділено тим ознакам і рисам характерів, завдяки яким козаки помітно впливали на оточення $і$ на ворогів, були непереможними в бою. Показано спрямованість думок, дій $i$ всього способу життя козаківхарактерників на досягнення найвищого блага і добра Украйни та украйниів.

Ключові слова: характер, козаки.

В статье изучено необычные проявления казаков в романе П. Панча «Шумела Украина». Внимание уделено тем признакам и чертам характеров, благодаря которым казаки значительно воздействовали на окружение и на врагов, были непобедимыми в бою. Показано направленность мыслей, действий и всего способа жизни казаков-характерников на достижение наивысшего блага и добра для Украины и украинцев.

Ключевые слова: характер, козаки.

In the article we research outstanding features in kosaks' characters in the novel of P. Panch "Homonila Ukraina". We pay attention to those features which allowed kosaks to influence noticeably their environment and enemies, be invincible in battles. It is shown that all outstanding kosaks' way of thinking, acting and living is directed to gain the best good for Ukraine and Ukrainians.

Key words: characters, kosaks.

Духовність людини привертає останнім часом особливу увагу дослідників. Вони розглядають іï під різними кутами зору і 3 різних позицій. В. Фащенко, В. Дончик, Є. Кирилюк, О. Білецький, А. Шпиталь та інші творчість Петра Панча i, зокрема, роман «Гомоніла Україна» (1954) дослідили більш ніж грунтовно. I все-таки проблеми й питання духовності та характерництва козаків так і не стали предметами спеціального та системного досліджень. В. Дончик відзначив, що П. Панч «досягає виявлення духовної сутносmi...» Б. Хмельницького [Панч 1972: 26], а про духовність інших 
персонажів не сказав фактично нічого. Поповнення цієї «прогалини» і стало метою даної статті.

Від самого початку роману письменник розкриває неоднозначний характер Богдана: «Молодий Хмельницький мав бурхливу вдачу. Звичайно лагідний і стриманий, на слово дотепний, кмітливий у скруті - у гніві був страшний» [Панч 1972: 119]. При цьому романіст зазначає, що природно-генетичне в характері Богдана брало верх над соціально набутим («Тоді прокидався в ньому степовик з буйною силою, якої не могли вже стримати ні прищеплена в колегіумі єзуїтами вдаваність, ні шляхетська вихованість. Саме таких любили січовики, щуо не знали меж своїм пристрастям» [Панч 1972: 119]). Можливо, тому героєві й щастило в житті: «3 $<\ldots>$ походу не багато повернуло козаків на Запорожжя, але молодого Хмеля і изього разу обминула смерть, а доля ще й пофортунила: пішов він на татар простим козаком, а повернувся вкритим славою отаманом» [Панч 1972: 119].

Автор показав, що незважаючи на зневіру в пошуках достойного керівника («- Багато їх хапалося за булаву, аж доки не впустили на лід. Ні, братику, перевелися Байди Вишневецькі, Яремами стали» [Панч 1972: 140]), козаки чекали появи бажаного гетьмана - недарма ним став Богдан Хмельницький.

За допомогою виразних рис портрета Хмельницького, яким побачив його Максим Кривоніс, автор передає його інтелект і волю після «хазяйнування» Чаплинського на його хуторі в Суботові: «Несподіване лихо не зігнуло ще иієї кремезної постаті, хіба щзо широкі плечі трохи опустилися. Довгасте смугляве обличчя було чисто поголене, а чорне, на лоб начесане й високо підрізане волосся на круглій голові ще лисніло, мов вороняче крило. Такі ж були й тонкі вуса під рівним носом. Вони лежали двома скибами довкола упертого рота з чітко окресленими губами. У великих сірих очах на дні світилась думка, яка розумом осявала все личе. <..> Кривоніс подумав про себе: "Оие той $і$ є один, по якому журиться Україна”》 [Панч 1972: 124]. 
Упродовж усього твору митець подав роздуми Хмельницького-політика від особистих інтересів до визвольної боротьби: «... тепер Хмельницький, як ніколи, побачив, щзо і вся Украӥна була в такому стані, як і його хутір» [Панч 1972: 265]; «... значить, таки правду каже Кривоніс, щзо треба козакам покладатися на шаблю. < .. > але й без дипломатії не можна» [Панч 1972: 42].

Підкреслюючи надзвичайну дію Хмельницького на козаків, романіст говорить: «Його голос справив магічний вплив: за якусь хвилину всі верхівиі не тільки були вже в сідлах, а й намащували руків'я шабель» [Панч 1972: 272]. У творі наголошується, що Богдан впливав на козаків також і своєю зовнішністю: зокрема, коли після першої незначної перемоги він наздогнав козаків поблизу Січі, то «... був блідий, але очі горіли, вся постава видавалась рішучою й сановитою. Може, саме ие вплинуло на людей» [Панч 1972: 300].

Автор робить спробу відтворити політичні думки і вчинки майбутнього гетьмана України: «Пройти перед січовиками парадом спало Богданові Хмельницькому на думку в останню хвилину. Було ие несподіванкою для всіх його споборників, але й бажане $<\ldots>$ A тепер він мусить не показом сили, а покорою прихилити до себе січове товариство» [Панч 1972: 301]; «3 появою на майдані чигиринського сотника в колі дужих, в поставі красивих козаків над куренями хвилею пройшло захоплення: очі січовикам заблищали, посмішки заграли, і слава Хмельницького сама по собі помножилась» [Панч 1972: 316].

Отже, зовнішність Богдана стає проявом його високого духу добротворення, і саме такий зовнішній вигляд гетьмана впливає на козаків: «Щойно в руці Богдана Хмельнищького опинилася булава, як обличчя його враз видовжилось, очі розширились, губи стиснулись, плечі розправились, і вся постава випросталась, стала сановитою, рішучою, величавою. Богдан Хмельнищький підніс булаву, $i$ враз усе завмерло» [Панч 1972: 318]. Ще виразніше все це передається в такому епізоді: «В иеей час знову задзвонили дзвони $і$ від усіх сотень і куренів рушили прапороносиі. Було таке враження, ніби 
на гетьмана вітер жене язики полум'я, а наблизившись, вони перед вогнем гетьманових очей припали до землі $і$ на якусь хвилю упокорились, скам'яніли» [Панч 1972: 321].

Заради великої справи Богдан йде на пожертву своїм сином Тимошем в якості застави: «Богдан Хмельнищький враз посмутнів, повільно оглянув усіх і ще повільніше сказав, повертаючись до Тимоша: <..> - Трудно, сину, а так треба» [Панч 1972: 314], проявляючи себе як талановитий державотворець.

Далі П. Панч пояснює, що полководець ретельно зважував кожне своє рішення: «Остаточне рішення Хмельницький вирішив прийняти перед самим боєм, а зараз лиме обдумував можливі варіанти» [Панч 1972: 388]. Митець показує Богдана таким знавцем тактики ведення бою та перемовин, що вороги приписують йому надприродні здібності: «Хмельницький наче читає твої думки» [Панч 1972: 408], - говорять польські посли.

Підкреслюючи неабиякі стратегічні вміння Богдана Хмельницького, письменник зауважує, що «заколисавщи» увагу поляків, «козацький гетьман тим часом зібрав своє військо і підвів його до кордонів Речі Посполитої» [Панч 1972: 479]. То ж не дарма ректор київської колегії Інокентій Гізель порівнює Богдана Хмельницького з біблійним персонажем Мойсеєм: «Колегіум пишається своїм учнем, щуо став християнської віри оборонителем $і$ свого народу освободителем. Як Мойсей вивів свій народ із Єгипту, так ти, преславний гетьмане, вивів із лядської темниці православних» [Панч 1972: 533].

Богдан Хмельницький довіряв і покладав великі надії на козаків-однодумців: «От Максим Кривоніс - той вірить, вірить, щэо ніяка сила не вистоїть проти народного гніву, а це вже половина перемоги» [Панч 1972: 305], - говорить він про Максима Кривоноса. Цього козака й автор виокремлює вже з самого початку твору, акцентуючи увагу не стільки на його зовнішності, скільки на його рішучості: «Вкрите шрамами обличчя з горбатим носом, випнуте підборіддя, гострий погляд з-під острішкуватих брів $і$ довгі вуса 
над рухливим ротом робили його подібним до яструба»; «Старшини дивилися на нього з повагою» [Панч 1972: 36]. I в подальших епізодах П. Панч постійно показує, з якою повагою ставилися до свого ватаги козаки, а про його «гострі очі, як ножі» говорить козак Верига [Панч 1972: 57]. Далека ж від боїв дівчина Текля 3 переляком сказала: «Він наче очима балакає» [Панч 1972: 36]. Поглядові Кривоноса дехто з персонажів приписував навіть чаклунські властивості: «Той такий, як гляне, так на сажень під землю бачить!» [Панч 1972: 91]. I справді, цей козацький ватажок мав деякі надлюдські здібності і «...вигляд грізного отамана, одного погляду якого було досить, щуоб пан від страху угруз у землю» [Панч 1972: 361].

Романіст відзначає, що слава Кривоноса поширилася далеко за межами України. Так, польський воєвода Адам Кисіль «добре знав норов козаків, але найбільше боявся Кривоноса» [Панч 1972: 83], а польський полковник Кричовський ще ширше характеризує Максима Кривоноса: «Цей збойцяя дався узнаки і волоському господареві, і султанові турецькому, навіть гішпанці знають його, а татарські мурзи з походів повертають, як зачують попереду Кривоноса» [Панч 1972: 83].

Красномовним видається епізод зустрічі Максима Кривоноса 3 трьома жовнірами на пасіці: «Кривоніс насупив брови, по обличчю перебігли брижами тіні, а очі враз почервоніли. $<\ldots>$ в взявся за руків'я шаблі» [Панч 1972: 179]. А старий пасічник ще й додав: «- Тікай, пане, бо Кривоніс до пупа розколе!» [Панч 1972: 179]. А з репліки, коли автор пише, що «Одні ним защитькували дітей, інші втихомирювали надто собачних дозоричів, $і$ ті при згадияі про Кривоноса мимоволі втягали голову в плечі» [Панч 1972: 229], можна задуматися над його характерницькими рисами.

Показуючи козацького ватажка і в особистих стосунках, письменник розкриває його сильний характер. Наприклад, закохавшись в Ярину, Максим зізнався їй по-особливому: «Нікому не вклонявся Максим Кривоніс: ні панові своєму, ні султанові турець- 
кому, ні ханові кримському, ні господареві волоському, ні королеві франиузькому навіть, а тобі, дівчино, до землі вклонюся, як своїй совісті...» [Панч 1972: 67-68]. У саму душу дивився цей незвичайний козак його коханій і в той же час «... скільки ласки в його очах, в його любій розмові» [Панч 1972: 67, 101]. То ж не дарма Ярина стала вірною помічницею такому чоловікові у визвольній боротьбі. А загалом: "Не заради женихання він вибрався із Низу на волость, настав час покласти край солодкому спокоєві Речі Посполитої, купованому горем украӥнського народу» [Панч 1972: 84], так, перемежовуючи особисте і суспільне, говорить про Кривоноса сам автор.

Дуже показовим видається епізод поєдинку Кривоноса 3 Яремою Вишневецьким: «Лють потроїла сили Кривоносові, він, як снопи, розкидав перед собою драгунів, валив їх шаблею. Нарешті до Вишневецького залишилось з три кроки. Князь озирнувся, $і$ їхні очі зустрілися: ще мить - i ніяка сила не зможе перешкодити розлюченому Кривоносові розрубати його надвоє» [Панч 1972: 441]. Це класичний зразок змалювання того, як у людини зароджується й міцніє сила характерництва.

Автор згадує про славного прадіда Яреми - Дмитра Вишневецького, який «Козакуючи на Низу, <..> здобуває любов $і$ шану товариства і стає вже Байдою Вишневецьким...», який, у народному уявленні, «не міг загинути звичайною смертю...»-він «навіть висячи на гаку, не перестає мститися на невірних...» [Панч 1972: 215-216].

У формі народного переказу романіст розповів і про непереможного богатиря Іллю Муромця [Панч 1972: 190] та про Нестора Морозенка, від згадки лише імені якого «иляхта скидалась у сні» [Панч 1972: 479]. Серед другорядних персонажів-козаків митець виокремлює Івана Богуна: «Від Богуна не відстають $і$ його козаки, ніби не рубають, а десь косять жито - $i$ направо, $і$ наліво» [Панч 1972: 487]. 
Та й побратими Мітла і Півень проявили себе досить незвично - i їх почали вважати за характерників. Так, коли Півня послав Богдан Хмельницький переманити реєстрових воїнів на свій бік, то Півень на запитання, чи він, часом, не характерник, відповів: «Може, й такий. От скажу, щоб ви переходили до козаків-запорожиів, вони за віру православну б'ються, за старожитні вольності, і перейдете» [Панч 1972: 381]. «I він почав із запалом розповідати все, що чув, що знав про підступи польської шляхти, про сподівання сотника Хмельнииького» [Панч 1972: 382], - ефект був надзвичайний: «3 кожним його словом усе більше грудилось коло нього козаків, все більще зморщок набігало їм на засмаглі чола. < ..> У козаків від здивування поширилися очі. < ..> Козаки справді замислились» [Панч 1972: 382].

Та й Мітла повів себе неординарно в одному з боїв, коли «Розлючений поляк підкинув до ока муикет і стрельнув. Мітла розпачливо ойкнув, схопився за бік, потім поліз до пазухи і витяг жолудь:

- Диви, які щедрі стали пани-ляхи: жолудями стріляють. Це ж для таких, як ви, найкраща їжа!» [Панч 1972: 399]. Розлютивши поляків і розваживши козаків, така імітація характерництва дала свої переможні наслідки.

У романі П. Панч подає і власне бачення зовнішності козакахарактерника, зокрема кобзаря Кирила Кладиноги [Панч 1972: 47], який не просто гине, виконуючи відповідальне завдання Богдана Хмельницького [Панч 1972: 427], а проявляє тим зразок героїзму.

Таким чином, автор у романі «Гомоніла Україна» показав, як Богдан Хмельницький, впливаючи своїм виключним інтелектом та масштабністю мислення, надпотужною волею, знанням людської психіки й психології, талантом бойового стратега і тактика не тільки здобуває собі ім'я славного та унікального захисника волі України, а й так впливає на козацьких ватажків Максима Кривоноса, Івана Богуна, Нестора Морозенка та на ряд простих козаків, що вони самі відкривали в собі їхі надзвичайні і навіть дивовижні 
здібності - здібності характерників. А головне, все те всіма ними разом спрямовувалося і перед боями, і під час зіткнень на досягнення найвищого блага і добра України і українців - на визволення нації і православної віри від озвірілої навали поневолювачів. Саме всім цим романіст показує вищі прояви душ, духу і духовності козацтва й спрямовує думки та свідомість читачів на осягнення вищих цінностей народу - незалежності, здатності володіти силою своєї волі й творити дива для конкретної перемоги.

\section{БІБЛІОГРАФІЯ}

Білецький 1990 - Білецький О. Столітній Панч / О. Білецький // Літературнокритичні статті / О. Білецький. - К. : Дніпро, 1990. - С. 150-153.

Гаврилова 2000 - Гаврилова Г. Роман П. Панча «Гомоніла Україна» в контексті художнього відображення подій хмельниччини / Г. Гаврилова // Українська література в загальноосвітній школі. - 2000. - № 1. - С. 58-63.

Кирилюк 1989 - Кирилюк Є. Література народної правди : статті, портрети / Євген Кирилюк. - К. : Рад. письменник, 1989. - 351 с.

Козлов 2005 - Козлов А. В. Духовність як літературознавча категорія : монографія / Анатолій Васильович Козлов. - К. : Акцент, 2005. - 272 с.

Панч 1991 - Панч П. Із щоденникових записів, дорожніх нотаток / П. Панч // Вітчизна. - 1991. - № 8. - С. 166-180.

Панч 1972 - Панч П. Твори : в 4 т. / Петро Панч. - К. : Дніпро, 1972.- Т. 1 / вступ. ст. В. Дончика. $-1972 .-551$ с.

Фащенко 1970 - Фащенко В. В. Жанрово-стилевые проблемы украинской советской новеллистики : автореф. дис. на соиск. уч. степени доктора филол. наук : спец. 642 «Литература народов СССР» (Украинская литература) / В. В. Фащенко. - К., 1970. - 59 с.

Шпиталь 2004 - Шпиталь А. Дві «цеглини» на наші голови: Про дилогію Н. Рибака «Переяславська рада» і не тільки про неї / А. Шпиталь // Українська мова і література. - 2004. - № 15. - С. 3-7.

Стаття надійшла 15 лютого 2013 p. 